\title{
Prevalence of antibodies to bluetongue virus in large ruminants of Marathwada region of Maharashtra state
}

\author{
S. D. Raut, V. V. Deshmukh and A. Aziz \\ Department of Microbiology, \\ College of Veterinary and Animal Sciences, Maharashtra Animal and Fishery Sciences University (MAFSU), \\ Parbhani, Maharashtra, 431402 India \\ Corresponding author: V. V. Deshmukh, email:vivekdes@gmail.com \\ Received: 27-10-2012, Accepted: 21-11-2012, Published online: 19-04-2013
}

\section{How to cite this article:}

Raut SD, Deshmukh VV and Aziz A (2013) Prevalence of antibodies to bluetongue virus in large ruminants of Marathwada region of Maharashtra state, Vet World 6(7):416-418, doi: 10.5455/vetworld.2013.416-418

\begin{abstract}
Aim: Seroprevalence study of BT antibodies in large ruminants of Marathwada region of Maharashtra state.

Materials and Methods: A total of 246 serum samples of Cattle and Buffalo were screened for qualitative analysis of the BTV antibodies using a commercial competitive ELISA (cELISA) kit.

Results: The results showed an overall percentage of BTV positive cattle and buffalo serum samples were $89.80 \%$ and $80 \%$ respectively. The results based upon the serum samples showing optical density values more than 50 per cent of the mean of negative control were taken as positive for presence of BTV antibodies. A high percentage of cattle showed BTV antibodies in places Parbhani (92.53\%), Nanded (86\%) and Aurangabad (81.81\%). The percentage of BTV antibodies in buffaloes was $70 \%, 100 \%, 100 \%$ and $87.5 \%$ respectively in Parbhani, Nanded, Aurangabad and Hingoli.
\end{abstract}

Conclusion: BTV antibodies were widely prevalent in cattle \& buffaloes of Marathwada region and cELISA were found to be sensitive and effective for screening of BTV group specific antibodies.

Keywords: bluetongue, cELISA, large ruminants, seroprevalence

\section{Introduction}

Bluetongue (BT) is a primarily midge-borne hemorrhagic viral disease mainly in sheep and occasionally in cattle and some species of deer [1]. The global distribution of bluetongue virus (BTV) has historically been between latitudes of approximately $40^{\circ} \mathrm{N}$ and $35^{\circ} \mathrm{S}$; however, the virus recently has spread far beyond the upper limit of this traditional range in northern Europe [2]. The distribution of BTV coincides with the distribution of competent culicoides insect vectors and appropriate climatic conditions [3]. However, specific vectors exist with specific constellations of BTV serotypes and topotypes in relatively distinct global ecosystems [4].

There are 24 distinct BTV serotypes and recently Toggenburg orbivirus (TOV) is proposed to be a 25 th serotype [5] and, complete genome characterization of a 26th BTV serotype from Kuwait [6]. It is a notifiable disease of the World Organization for Animal Health (Office of international epizooties: OIE) due to its economic impact [7]. In cattle, goats and most wild ruminant species BTV is typically asymptomatic or subclinical, although specific strains of BTV, like the strain of serotype 8 currently circulating in Europe, can cause severe disease in cattle and goats [8]. BT was first reported in India in 1961 in

This article is an open access article licensed under the terms of the Creative Commons Attribution License (http://creativecommons. org/licenses/by/2.0) which permits unrestricted use, distribution and reproduction in any medium, provided the work is properly cited. the state of Maharashtra [9]. Since then, the disease has been recorded in 11 states in India, either on the basis of virus isolation or by the detection of group-specific antibodies against the virus [10].

Bluetongue virus (BTV) is the causative agent of bluetongue disease in cattle, an insect transmitted disease of ruminants [11]. BTV belongs to Orbivirus genus of family Reoviridae. It has double stranded segmented RNA genome having ten discrete segments. The seven of these segments encode structural protein (VP1 to VP7) and the remaining three encode for non structural proteins (NS1, NS2, NS3 and NS3A), NS3 and NS3A are encoded by tenth segment [12]. The virus is transmitted within its vertebrate hosts via bites of culicoides species. BTV infection of cattle is typically sub clinical and manifested by fever, sever salivation, oral ulceration, excoriation, pityriasis, burnt muzzle, coronitis and lameness due to laminitis [13]. Abortions, Infertility and foetal Anomalies have also been attributed to BTV infection [13]. It is also characterized by prolonged viremia [14] during which the virus invariably is cell-associated [15].

The virus remains in large ruminants for a limited period (40-45 days) however; frequency of presence of BTV group specific antibodies in large ruminants is very high. The seroprevalence studies in cattle and buffaloes in the particular BTV ecosystem have given valuable information about its epidemiology. In cattle the seroprevalence of BTV varies from 6 to 79 percent. However, only 1 to 10 percent of these seropositive cattle developed clinical disease [16]. The competitive 
Table-1. Prevalence of BT Antibodies in Cattle $\&$ Buffaloes as Determined by cELISA

\begin{tabular}{lcccccc}
\hline Disricts & \multicolumn{2}{c}{ Total Examined } & \multicolumn{2}{c}{ No. of Positive } & \multicolumn{2}{c}{ Percent Positive } \\
& Cattle & Buffaloes & Cattle & B uffaloes & Cattle & B uffaloes \\
\hline Parbhani & 134 & 20 & 124 & 14 & 92.53 & 70 \\
Aurangabad & 22 & 02 & 18 & 02 & 81.81 & 100 \\
Nanded & 50 & 02 & 43 & 02 & 86.00 & 100 \\
Hingoli & -- & 16 & -- & 14 & -- & 87.5 \\
\hline
\end{tabular}

enzyme-linked immunosorbent assay (cELISA) is a superior test for serologic diagnosis of BTV infection of ruminants because it requires significantly less time to run, and provide objective results [17]. It is also approved by OIE for testing BTV infection in international trade of livestock.

The purpose of the present communication is to present the results of seroprevalence study of BT antibodies using cELISA in large ruminants of Marathwada region of Maharashtra state.

\section{Materials and Methods}

Collection of Serum samples: About 5-7 $\mathrm{ml}$ of blood from cattle and buffalo was collected in $10 \mathrm{ml}$ sterile test tubes from various slaughter houses (Three) that receive the animals from adjoining districts and one organized farm of the Marathwada region in aseptic condition. Serum was separated and stored at -200C in small aliquots till use.

Antigen: The bluetongue group specific antigen supplied with bluetongue antibody test kit by Veterinary Diagnostic Technology, (VDT) Inc. USA was used in the cELISA test.

Competitive Enzyme-linked I mmunosorbent Assay (CELI SA): The test was performed as per the procedure given in the manual of Veterinary Diagnostic Technology; Inc., provided with bluetongue antibody test kit. The PI of the monoclonal antibody for each serum control and test sample was done as per the formula of bluetongue antibody test kit,

$\mathrm{PI}=100-[$ (adjusted average OD test sample)/(adjusted average OD test sample) $\times 100$.]

The samples were considered to be positive for BTV antibody if the PI value is $\geq 50$ percent. The samples with PIs less than 50 percent were considered negative.

\section{Results}

A serological survey involving 246 serum samples of cattle (206) and buffaloes (40) from various places was carried out employing cELISA for qualitative analysis of the BT antibodies (Table-1). The serum samples showing optical density values $>50$ per cent of the mean of negative control were taken as positive for presence of BT antibodies.

A critical observation of (Table-1) indicates that a high percentage of cattle showed BT antibodies in various districts of Marathwada region as 92.53 percent in Parbhani, 86 percent in Nanded and 81.81 percent in Aurangabad. Similarly a high percentage of buffalo showed BT antibodies in various districts of Marathwada region as 70 percent in Parbhani, 100 percent in Nanded, 100 percent in Aurangabad and 87.5 percent in Hingoli. The overall percentage of BT positive cattle and buffalo was 89.80 and 80 percent respectively.

\section{Discussion}

Bluetongue virus infection has been reported in bovine from several countries on the basis of presence of BTV specific antibodies and isolation of virus. In areas where BT is endemic, the disease in cattle and buffalo is not clinically overt. In these areas seroconversion and viremia are the only evidences of infection. Although BTV infection of ruminants is often subclinical or in apparent, infection also can lead to severe disease with mortality in susceptible animals [18,19]. In different districts of Saudi Arabia seroprevalence of BTV antibodies observed, in that $49.3 \%$ of cattle, in Jizan and $53.4 \%$ of cattle in Eastern Province positive to c-ELISA, whereas in Najran district the seropositivity for Bluetongue was found to be $47.2 \%$ of cattle [20]. In southeastern turkey, the presence of BTV was investigated serologically in 100 cattle and were detected as $88 \%$ [21].

The results in present study are in agreement with observations of earlier workers. In 2004, four regions of Gujarat State, the study was undertaken to screen sera of cattle and buffaloes for the presence of BTV group specific antibodies employing BT-AGID and cELISA. The seroprevalence in cattle and buffaloes recorded was 48.82 and 39.29 per cent by BT-AGID and 69.19 and 58.33 percent by c-ELISA, respectively [22]. In the state of West Bengal, the seroprevalence of BTV in a sample population of 50 cattle, by indirect ELISA, revealed $52 \%$ of seroprevalence [23]. In buffaloes a total of 173 sera sample tested by BTAGID, CCIE and c-ELISA, for the presence of BTV antibodies and the seroprevalence observed was 35.26 , 39.88 and 60.12 percent respectively [24].The seroprevalence of 17 percent and 9 percent was reported by using agar gel precipitation test in cattle and buffaloes, respectively [25]. The AGID were used and observations were similar to the earlier workers [26]. Similarly by using cELISA seroprevalence study was conducted and recorded seropositivity of 30.76 percent among cattle, 37.14 percent in buffaloes, 40.36 percent among sheep and 64.86 percent among goats [27]. However, in present study 100 percent seroprevalence in buffaloes at Nanded and Aurangabad may be due to small sample size and need further studies. The overall 
percentage of BT positive animals was given 47.01 percent.

\section{Conclusion}

The cELISA being a highly sensitive, specific and rapid test was found to be advantageous in present study. High percentages of BT antibodies in cattle and buffaloes may be due to circulation of BTV in large ruminants in the form of inapparent infection. Surveillance of cattle and buffaloes in BT endemic areas for clinical observations in addition to routine seroprevalence will be of great help to understand BT epidemiology for formulating effective control strategies.

\section{Authors' contribution}

The study was a part of M.V.Sc thesis submitted to MAFS University by SDR under the guidance of VVD. AA was a member of advisory committee. All author contributed equally. All authors read and approved the final manuscript.

\section{Acknowledgements}

The authors are thankful to Indian Council of Agricultural Research, All India Network Programme on Bluetongue for providing necessary facilities and fund to carry out this work.

\section{Competing interests}

Authors declare that they have no competing interest.

\section{References}

1. Mertens, P.P.C., Maan, S., Samuel, A. and Attoui, H. (2004) Orbivirus, Reoviridae, In: Fauquet, C.M.; Mayo, M.A.; Maniloff, J.; Desselberger, U.; Ball, L.A., (Eds.), Virus taxonomy, VIII ${ }^{\text {th }}$ report of the ICTV, Elsevier/Academic press, London, UK., 466-483.

2. Saegerman, C., Berkvens, D. and Mellor, P.S. (2008) Bluetongue epidemiology in the European Union. Emerg Infect Dis 14:539-544.

3. Jafari-Shoorijeh, S., Ramin, A.G., Maclachlan, N.J., Osburn, B.I., Tamadon, A., Behzadi, M.A., Mahdavi, M., Araskhani, A., Samani, D., Rezajou, N. and Amin-Pour, A. (2010) High seroprevalence of bluetongue virus infection in sheep flocks in West Azerbaijan, Iran. Com. Immunol. Microbiol. Infect. Dis. 33:243-247.

4. Balasuriya, U.B., Nadler, S.A., Wilson, W.C., Pritchard, L.I., Smythe, A.B., Savini, G., Monaco, F., De Santis, P., Zhang, N, Tabachnick, W.J. and Maclachlan, N.J. (2008) The NS3 proteins of global strains of bluetongue virus evolve into regional topotypes through negative (purifying) selection. Vet. Microbiol. 126:91-100.

5. Hofmann, M.A., Renzullo, S., Mader, M., Chaignat, V., Worwa, G. and Thuer, B. (2008) Genetic characterization of Toggenburg orbivirus, a new bluetongue virus, from goats, Switzerland. Emerg. Infect. Dis. 14: 1855-1861.

6. Maan, S., Maan, N.S., Nomikou, K., Batten, C., Antony, F., Belaganahalli, M.N., Samy, A.M., Reda, A.A., Al-Rashid, S.A., El Batel, M., Oura, C.A. and Mertens, P.P. (2011): Novel bluetongue virus serotype from Kuwait. Emerg. Infect. Dis. 17:886-889.

7. World Organization for Animal Health (2010) Bluetongue, chapter 8.3, Terrestrial Animal Health Code, 19th edition OIE, paris 448-463.

8. Elbers, A.R.W., Backx, A., Mintiens, K., Gerbier, G.,
Staubach, C., Hendrickx, G. and Van der Spek, A. (2008) Field observations during the bluetongue serotype 8 epidemic in 2006. II. Morbidity and mortality rates, case fatality and clinical recovery in sheep and cattle in the Netherlands. Prev. Vet Med, 87:31-40.

9. Sapre, S.N. (1964) An outbreak of 'bluetongue' in goats and sheep in Maharashtra state, India. Vet. Rev. (M\&B), 15: 6971.

10. Prasad, G. (2000) Whither bluetongue research in India. Indian J. Microbiol., 40 (9), 163-175.

11. Erasmus, B.J. (1975) Bluetongue in sheep and goats. Aust. Vet. J., 51:165-170.

12. Scientific committee on animal health and animal welfare, June (2000) Possible use of vaccination against bluetongue in Europe. Europian commission, health and consumer protection directorate general, 1-25.

13. Castro, A.E. and Rodger, S.J. (1984) Congenital anamolies in cattle associated with an epizootic of bluetongue virus (serotype 11). Bovine Pract., 19:87-91.

14. Richards, R.G., Heidner, H.W., Maclachlan, N.J. and Fuller, F.J. (1988) Comparison of virologic and serologic responses of lambs and calves infected with bluetongue virus serotype 10. Vet. Microbiology, 18: 233-242.

15. Parsonson, I.M., Della-Porta, A.J., Mcphee, D.A. Cybinski, D.H., Squire, K.R.E. and Uren, M.F. (1987) Experimental infection of bull and cows with bluetongue virus serotype 20. Aust. Vet. J., 64:10-13.

16. Osbum, B.I., Huffman, E.M. and Sawyer, M. (1986) Economics of bluetongue in the united states in: Arbovirus research in Australia, ed. George TD, Kay BH, Block J, CSIRO Melbourne, Australia., 245-247.

17. Reddington, J.J., Reddington, G.M. and Maclachlan, N.J. (1991) A competitive ELISA for detection of antibodies to the group antigen of bluetongue virus. J. Vet. Diagn Invest, 3 : 144-147.

18. Maclachlan, N.J. (2011) Bluetongue: History, global epidemiology, and pathogenesis. Prev. Vet. Med. 102:107-111.

19. Maclachlan, N.J., Drew, C.P., Darpel, K.E. and Worwa, G. (2009) The pathology and pathogenesis of bluetongue. $J$. Comp. Pathol. 141:1-16.

20. Yousef, M. R.,Al-Eesa, A. A. and Al-Blowi, M. H. (2012) High seroprevalence of bluetongue virus antibodies in sheep, goats, cattle and camel in different districts of Saudi Arabia. Vet. World, 5 (7): 389-393.

21. Gur, S. (2008) A serologic investigation of blue tongue virus (BTV) in cattle, sheep and gazella subgutturosa subgutturosa in southeastern turkey. Trop Anim Health Prod, 40:217-221.

22. Chauhan, H.C., Chandel, B.S., Vasava, K.A., Patel, A.R., Shah, N.M and Kher, H.N. (2004) Seroprevalence of bluetongue in Gujarat, Indian Journal of Comparative Microbiology, Immunology and Infectious Diseases, 25 (2): 80-83.

23. Panda, M. K., Mondal, A. and Joardar, S.N. (2011) Seroprevalence of bluetongue virus in sheep, goat and cattle in West Bengal, India, Animal Science Reporter, 5 (3):105-110.

24. Patel, A.R., Chandel, B.S., Chauhan, H.C., Vasava, K.A., Bhalodia, S.D., Pawar, D.W., Shah, N.M. and Kher, H.N. (2007) Prevalence of bluetongue virus antibodies in buffaloes of organized farms in Gujrat. Buffalo Bulletin, 26(1).

25. Kale, S.G. (2002) Studies on characterization of BT virus and its seroprevalence in domestic animals. M.V.Sc. thesis submitted to MAFSU, Nagpur, India.

26. Audarya, S.D. (2003) Studies on seroprevalence and molecular characterization of bluetongue virus isolate from ruminants. M.V.Sc. (Unpublished) Thesis, Maharashtra Animal and Fishery Sciences University, Nagpur, India.

27. Waghmare, S.G. (2005) Studies on seroprevalence of bluetongue virus in ruminants. M.V.Sc. Thesis submitted to MAFSU, Nagpur, India.

$* * * * * * * *$ 